\title{
Medicine in stamps: history of Down syndrome through philately
}

\section{Pullardaki tıp: filateli aracıliğtyla Down sendromu tarihi}

\author{
Ahmet Doğan Ataman', Emine Elif Vatanoğlu-Lutz², Gazi Yıldırım³ \\ 'Department of History of Medicine, Vienna Medical Faculty, Vienna, Austria \\ ${ }^{2}$ Department of Medical History and Ethics Medical Faculty, Yeditepe University, Istanbul, Turkey \\ ${ }^{3}$ Department of Gynecology and Obstetrics Medical Faculty, Yeditepe University, Istanbul, Turkey
}

\section{Abstract}

Down syndrome (DS) is one of the most common chromosomal disorders with mental retardation and some spesific physical and physiological defects. Recently, many advances have been made in pre-natal screening and detection; and the hope is that identification of more genes will lead to a better understanding of the molecular mechanisms underlying the pathologies, and hence to more effective therapy. This paper provides an overview on the discovery of Down syndrome through philately.

(J Turkish-German Gynecol Assoc 2012; 13: 267-9)

Key words: Down syndrome, mental retardation, genetics, history, philately

Received: 14 November, 2012

Accepted: 19 November, 2012

\section{Özet}

Down sendromu zihinsel gelişme geriliği ve kendine özgü fiziksel ve fizyolojik defektlerle seyreden, en sık rastlanan kromozom hastalıklarından biridir. Son dönemlerde hastalığın prenatal tarama ve tanısında birçok ilerlemeler kaydedilmiştir. Genlerin ve gen patolojilerinin altında yatan moleküler mekanizmaların daha iyi anlaşılaması daha etkili tedavi yöntemleri konusunda umut vermektedir. Bu çalışma, Down sendromunun tarihine filateli yoluyla ışık tutmaktadır.

(J Turkish-German Gynecol Assoc 2012; 13: 267-9)

Anahtar kelimeler: Down sendromu, zihinsel gerilik, genetik, tarih, filateli

Geliş Tarihi: 14 Kasım 2012

Kabul Tarihi: 19 Kasım 2012

\section{Introduction}

Down syndrome (DS), also known as trisomy 21, is caused by the presence of all or part of a third copy of chromosome 21 (Figure 1a, b). It is named after John Langdon Down, the British physician who described the syndrome for the first time in 1866. In 1866 he wrote a paper entitled "Observations on the Ethnic Classification of Idiots" in which he put forward the theory that it was possible to classify different types of conditions by ethnic characteristics. He listed several types including the Ethiopian type. He is most famous for his classification of what is known as Down syndrome, named after him, but which he classified as the Mongolian type of Idiot. As a result, Down syndrome was also known as "Mongolism" and people with Down syndrome referred to as "Mongoloids" but the use of the word 'mongolism' is now stopped after having so many criticisms about referring a racist title. Thus down syndrome occurs in all human populations, and analogous conditions have been found in other species such as chimpanzees (1).

The chromosome aberration was discovered in 1959 by the French human geneticist Jérôme Jean Louis Marie Lejeune (1926-1994). Dr. Jérôme Lejeune discovered that Down syndrome was caused by an extra chromosome on the $21^{\text {st }}$ pair while working in Raymond Turpin's laboratory In 1958. The French Academy of Sciences published his scientific work on January 26, 1959. For the first time in world history, his discovery established a link between an intellectual disability and a chromosomal abnormality. After this discovery, an enormous field of investigation was opened up for modern genetics and a new discipline was founded: cytogenetics. Until then, the knowledge about human heredity had been unable to explain Trisomy 21 and other anomalies in hereditary material (2).

Nowadays, down syndrome can be identified in a baby at birth, or by prenatal screening.

\section{Genetic Background}

Down syndrome is a complex set of pathologies caused by an extra copy of human chromosome 21 (Hsa21). DS occurs in about one in 750 live births and is the most frequent cause of learning difficulties (Figure 2). The underlying genetic cause, trisomy Hsa21, is the same in most individuals with DS, but the penetrance of the resulting pathologies (3).

Genes on an extra copy of chromosome 21 are responsible for all characteristics associated with Down syndrome. Normally, each human cell contains 23 pairs of different chromosomes. Each chromosome carries genes, which are

Address for Correspondence: Emine Elif Vatanoğlu-Lutz, İnönü Mah. Kayışdağı Cd. 26 Ağustos Yerleşkesi Kayışdağı 34755 İstanbul, Turkey

Phone: +9021657800 00/3078e.mail: drvatanoglu@yahoo.com

(C) Copyright 2012 by the Turkish-German Gynecological Education and Research Foundation - Available online at www.jtgga.org doi:10.5152/jtgga.2012.43 


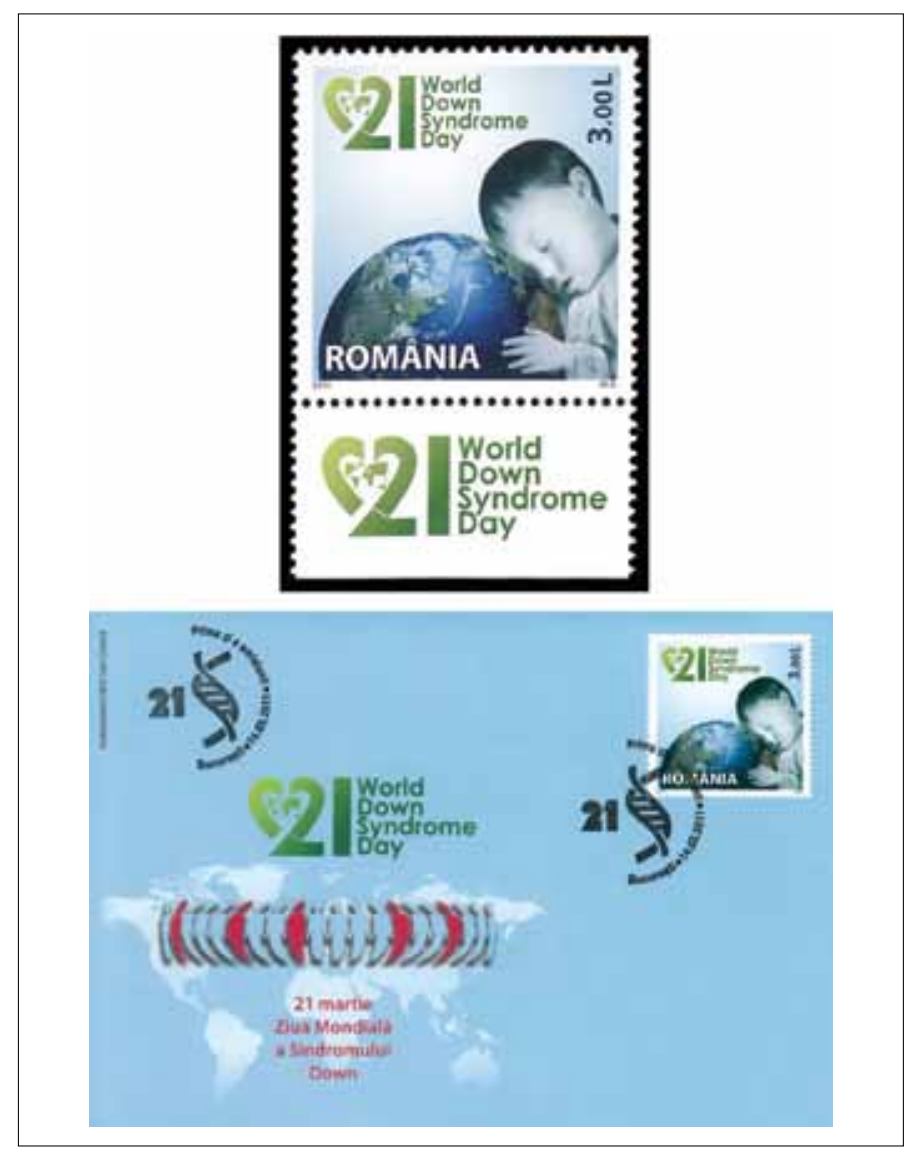

Figure 1. a) Stamp issued in Romania in 2011, for the $21^{\text {st }}$ of March Down Syndrome Day; b) First Day Cover from Romania in 2011, for the $21^{\text {st }}$ of March Down Syndrome Day

needed for proper development and maintenance of our bodies. At conception, an individual inherits 23 chromosomes from the mother (through the egg cell) and 23 chromosomes from the father (through the sperm cell) (3).

However, sometimes a person inherits an extra chromosome from one of the parents. In Down syndrome, an individual most often inherits two copies of chromosome 21 from the mother and one chromosome 21 from the father for a total of three chromosomes 21 (Figure 3). Because Down syndrome is caused by the inheritance of three chromosomes 21 , the disorder is also called trisomy 21 . About $95 \%$ of individuals with Down syndrome inherit an entire extra chromosome 21 (4).

Approximately 3\% to 4\% of individuals with Down syndrome do not inherit an entire extra chromosome 21 , but just some extra chromosome 21 genes, which are attached to another chromosome (usually chromosome 14). This is called a translocation. Most of the time, translocations are random events during conception (Figure 4). In some instances however, a parent is a balanced carrier of a translocation: The parent has exactly two copies of chromosome 21 , but some of the genes are distributed to another chromosome. If a baby inherits the chromosome with the extra genes from chromosome 21, then the child will have Down syndrome (two chromosomes 21 plus extra chromosome 21 genes attached to another chromosome) $(3,4)$.

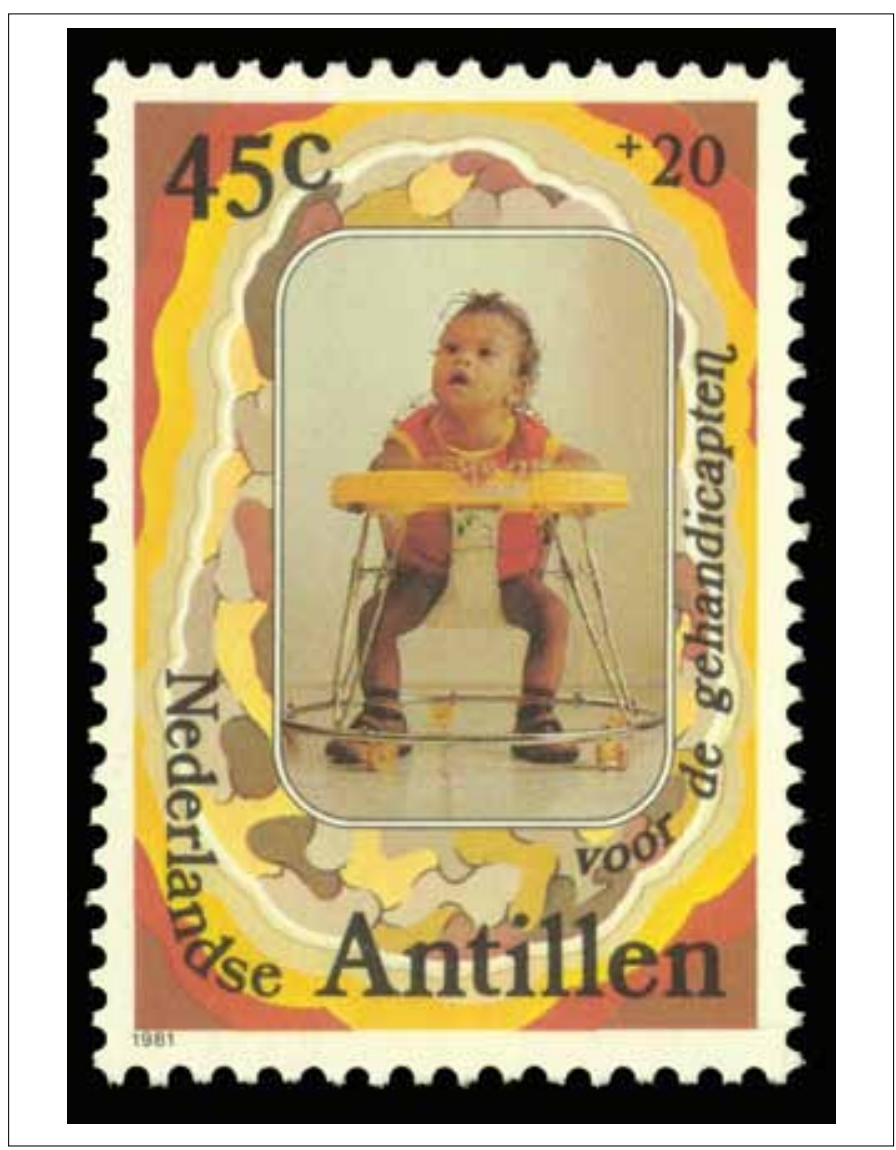

Figure 2. Stamp issued in 1981 by Netherlands Antilles, in support of handicapped children, for the International Year of the Disabled

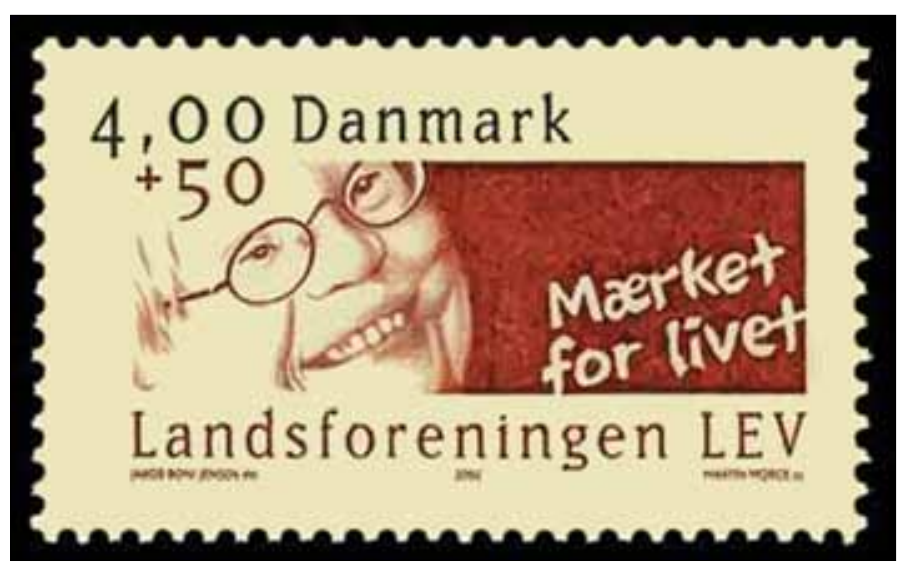

Figure 3. A stamp issued in Denmark in 2002

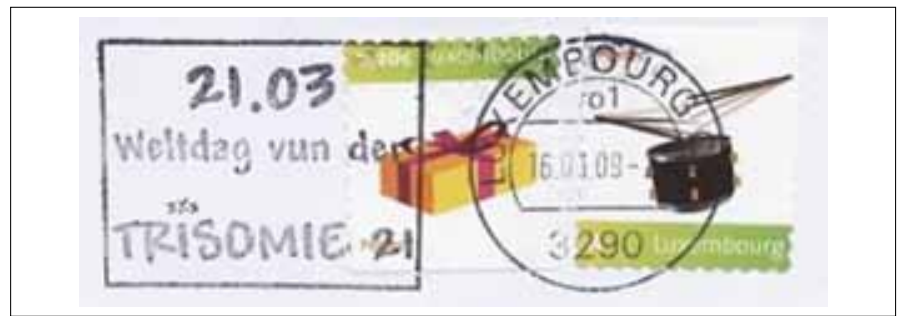

Figure 4. A special cancellation from Luxembourg in 2003, emphasising Trisomie 21 


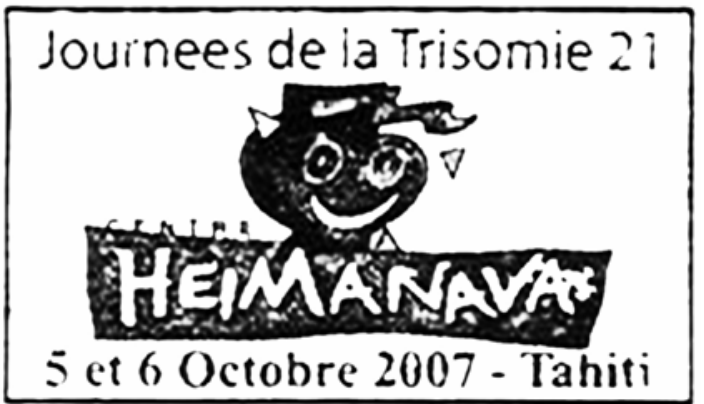

Figure 5. A special cancellation from Tahiti in 2007, emphasising Trisomie 21

About $2 \%$ to $4 \%$ of people with Down syndrome inherit additional genes from chromosome 21 , but not in every cell of the body. This is known as mosaic Down syndrome. These individuals may, for example, have inherited extra genes from chromosome 21 in their muscle cells, but not in any other type of cell. Because the percentage of cells with extra genes from chromosome 21 varies in people with mosaic Down syndrome, they often don't have all the typical physical characteristics and may not be as severely intellectually impaired as people with full trisomy 21 (Figure 5). Sometimes, mosaic Down syndrome is so mild that it will go undetected. On the other hand, mosaic Down syndrome can also be misdiagnosed as trisomy 21 , if no genetic testing has been done (3).

\section{Signs and Symptoms}

Most individuals with DS have memory and learning difficulties, craniofacial alterations and muscle hypotonia, but only some have congenital heart malformations, leukaemia or gut abnormalities. The severity of the defects is variable. For example, the extent of cognitive impairment varies widely between individuals with DS (5).

The signs and symptoms of Down syndrome are characterized by the neotenization of the brain and body to the fetal state. Down syndrome is characterized by decelerated maturation (neoteny), incomplete morphogenesis (vestigia) and atavisms. Individuals with Down syndrome may have some or all of the following physical characteristics: microgenia (abnormally small chin), oblique eye fissures with epicanthic skin folds on the inner corner of the eyes (formerly known as a mongoloid fold), muscle hypotonia (poor muscle tone), a flat nasal bridge, a single palmar fold, a protruding tongue (due to small oral cavity, and an enlarged tongue near the tonsils) or macroglos- sia, "face is flat and broad", a short neck, white spots on the iris known as Brushfield spots, excessive joint laxity including atlanto-axial instability, excessive space between large toe and second toe, a single flexion furrow of the fifth finger, a higher number of ulnar loop dermatoglyphs and short fingers (5).

Growth parameters such as height, weight, and head circumference are smaller in children with DS than with typical individuals of the same age. Adults with DS tend to have short stature and bowed legs. Individuals with DS are also at increased risk for obesity as they age (5).

\section{Conclusion}

Many children with Down syndrome who have received family support, special therapies and education manage to graduate from high school and are able to do paid work, and some participate in post-secondary education as well. Early childhood intervention, screening for common problems, medical treatment where indicated, a conducive family environment, and vocational training can improve the overall development of children with Down syndrome. As individuals with DS continue to experience longer lives, the need to understand their aging and associated health conditions becomes more critical. Education and proper care will improve quality of life significantly, despite genetic limitations. Especially adults with DS should be provided with appropriate information to better understand, and counseling to cope with, changes in their own level of ability or health.

\section{Conflict of interest}

No conflict of interest was declared by the authors.

\section{References}

1. Sturtevant AH. A History of Genetics, Columbia : Cold Spring Harbor Laboratory Press; 2001.p.121-8.

2. Snedden R. The History of Genetics, London : Thomson Learning Press; 1999.p.200-5.

3. Lana-Elola E, Watson-Scales SD, Fisher EM, Tybulewicz VL. Down syndrome: searching for the genetic culprits. Dis Model Mech 2011; 4: 586-95. [CrossRef]

4. Gaete B, Mellado C, Hernandez M. Prevalence of neurological disorders among children with Down syndrome. Rev Med Chil 2012; 140: 214-8. [CrossRef]

5. Esbensen AJ. Health conditions associated with aging and end of life of adults with Down syndrome. Int Rev Res Ment Retard 2010; 39: 107-26. [CrossRef] 